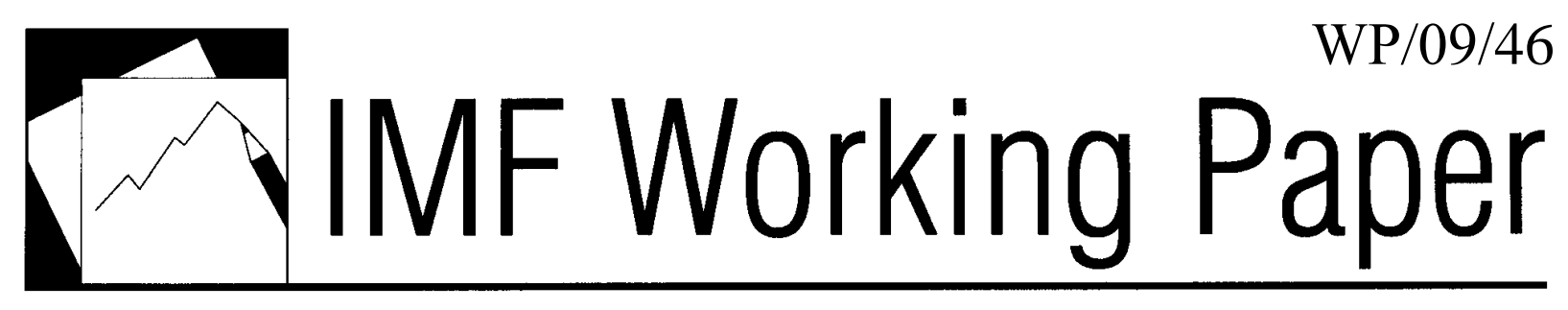

\title{
Sovereign Default, Private Sector Creditors and the IFIs
}

\author{
Emine Boz
}





\title{
IMF Working Paper
}

IMF Institute

\section{Sovereign Default, Private Sector Creditors and the IFIs}

Prepared by Emine Boz ${ }^{1}$

Authorized for distribution by Alexandros Mourmouras

March 2009

\begin{abstract}
This Working Paper should not be reported as representing the views of the IMF.

The views expressed in this Working Paper are those of the author(s) and do not necessarily represent those of the IMF or IMF policy. Working Papers describe research in progress by the author(s) and are published to elicit comments and to further debate.
\end{abstract}

This paper builds a model of a sovereign borrower that has access to credit from private sector creditors and an IFI. Private sector creditors and the IFI offer different debt contracts that are modelled based on the institutional frameworks of these two types of debt. We analyze the decisions of a sovereign on how to allocate its borrowing needs between these two types of creditors, and when to default on its debt to the private sector creditor. The numerical analysis shows that, consistent with the data; the model predicts countercyclical IFI debt along with procyclical commercial debt flows, also matching other features of the data such as frequency of IFI borrowing and mean IFI debt stock.

JEL Classification Numbers: F33, F34, G15

Keywords: emerging markets, sovereign debt and default, IFIs

Author's E-Mail Address: EBoz@imf.org

\footnotetext{
${ }^{1}$ I am grateful to Sheila Bassett, Pelin Berkmen, Enrica Detragiache, Ceyhun Bora Durdu, Chris Jarvis, Anton Korinek, Leslie Lipschitz, Enrique Mendoza, Ydahlia Metzgen, Alex Mourmouras, Marco Rossi as well as the participants of the World Congress of the International Economic Association in Istanbul, European Meetings of the Econometric Society in Milan, and IMF Institute Lunch Seminar for helpful comments and suggestions.
} 


\section{Contents}

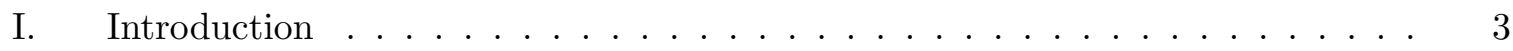

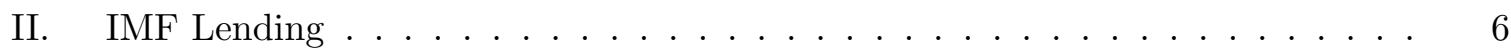

A. Institutional Framework $\ldots \ldots \ldots \ldots$. . . . . . . . 6

B. Cyclical Properties . . . . . . . . . . . . . . . 7

III. Model . . . . . . . . . . . . . . . . . . . . . . . . . . . . . . . . . . . 10

IV. Quantitative Analysis . . . . . . . . . . . . . . . . . . . . . 13

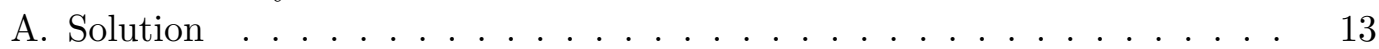

B. Calibration and Data . . . . . . . . . . . . . . . . . 14

C. Findings . . . . . . . . . . . . . . . . . . . 15

D. Sensitivity Analysis . . . . . . . . . . . . . . . . . . . 17

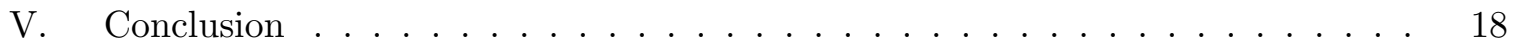

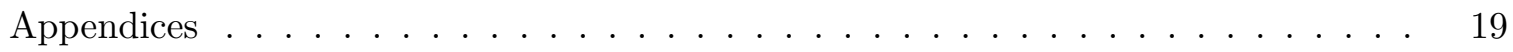

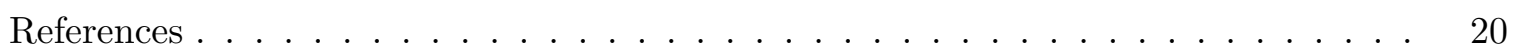

Tables

1. Average interest rates . . . . . . . . . . . . . . . . . 22

2. Data Moments: Private Sector Creditor Lending . . . . . . . . . . . . . . 22

3. Data Moments: IMF Lending. . . . . . . . . . . . . . . . . . . . . . 23

4. Spreads and Use of IMF Credit . . . . . . . . . . . . . . . . . . . . . 23

5. Probability of Use of IMF Credit . . . . . . . . . . . . . . . . . . . . . 24

6. Parameters . . . . . . . . . . . . . . . . . . . . . 24

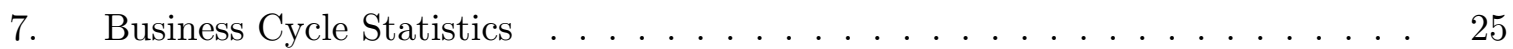

8. IFI Debt During High and Low Spreads . . . . . . . . . . . . . . . . . 25

9. IFI Debt During Booms and Busts . . . . . . . . . . . . . . . 25

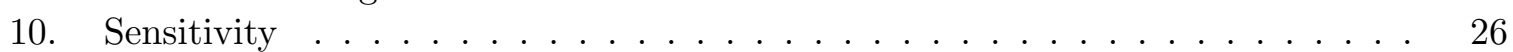

Figures

1. IMF Interest Rates vs U.S. Government Bond Yields . . . . . . . . . . . . 26

2. Commercial Debt Price Schedule, $q\left(d^{\prime}, d^{* \prime}, y\right) \ldots \ldots \ldots \ldots \ldots$

3. Stationary Bond Distributions for the Simple SOE Model . . . . . . . . . . 27 


\section{Introduction}

Sovereign borrower and creditor relationships have long been complicated by sovereigns' incentives to default on their debt. ${ }^{1}$ This paper contributes to the literature on sovereign debt and default by documenting the cyclical properties of lending by International Financial Institutions (IFIs) and introducing an IFI to a model with strategic default on commercial debt. The goal of the paper is to uncover the sovereign's allocation of its financing needs between private sector creditors and the IFI, as well as to account for the cyclical properties of IFI lending. ${ }^{2}$

Taking the International Monetary Fund (IMF) as an example, the data reveal that the cyclical properties of lending by IFIs are in stark contrast with those of private sector creditor lending. The average correlation of IMF debt flows with output for a group of emerging market economies is -0.15 , while the same correlation in the case of commercial debt flows is $0.37 .{ }^{3}$ In addition, the variability of commercial debt flows is about three times as large as that of IMF debt. Finally, countries do not borrow from the IMF at all times; we find the unconditional probability of the use of IMF credit to be around 50 percent. This is also in contrast with commercial debt, as all countries in our sample were indebted to private sector creditors at all times.

Motivated by these regularities, we propose an incomplete markets framework that features a sovereign, private sector creditors, and an IFI. The sovereign cannot commit to repay its debt to private sector creditors and thereby strategically defaults depending on the level of its commercial debt, official debt, and output. Punishment for default is exclusion from the commercial credit markets and direct output losses. Assuming perfectly competitive, risk-neutral private sector creditors, the interest rate charged by private creditors is determined by endogenous default probabilities.

The IFI offers a different contract than the private sector creditors. These differences are based on the institutional framework of the IMF loans, more specifically Stand-By Arrangements (SBAs). First, the sovereign can commit to repay its debt to the IFI. In other words, contracts with the IFI are enforceable while those with commercial creditors are not. This is loosely implied by the IFI having a preferred creditor status and also the fact that the IMF has almost always been repaid particularly by the emerging market economies that we focus on in this paper. Second, the interest rate associated with IFI lending is assumed to be the sum of the risk free rate and a charge that increases with the amount borrowed from the IFI. This specification for the IFI interest rate captures the surcharges that may apply in the case of SBAs depending on the amount borrowed. ${ }^{4}$ Note that this is significantly different from commercial interest rates, as those depend on the endogenous default probability determined by the "riskiness" of the sovereign. Finally, conditionality associated with IFI debt is accounted for by a higher discount factor in periods when the sovereign is indebted to the IFI. In this setting, the higher discount factor tilts the consumption profile by shifting consumption from the present to the

\footnotetext{
${ }^{1}$ Reinhart, Rogoff and Savastano (2003) document that sovereigns borrowed and defaulted since the 19th century with the maximum number of defaults incurred by Venezuela (9) and Mexico (8).

${ }^{2}$ Throughout the paper, we use the term "commercial debt" to refer to debt to the private sector creditor and "official debt" to refer to debt to the IFI.

${ }^{3}$ See Section 2 for more details on the data and calculations.

${ }^{4}$ See Section 2 for details of the institutional framework of SBAs.
} 
future, thereby lowering debt levels and default probabilities. This can be interpreted as similar to implementing tighter fiscal policies that have traditionally been part of IMF conditionality. ${ }^{5}$

The model featuring the aforementioned types of creditors, when calibrated to Argentina, a representative emerging market economy, performs well in matching several features of the data. First, it generates procyclical commercial debt as well as countercyclical IFI debt. In good times, the sovereign finds it optimal to borrow more commercially at relatively lower rates, with lower default probability and without incurring the costs associated with borrowing from the IFI. However, in bad times, in order to avoid the high risk premia charged by private sector creditors, the sovereign reallocates its portfolio by giving more weight to borrowing from the IFI.

The sovereign's default probability increases with the level of official debt as it does with commercial debt. The relationship between the default probability and commercial debt has already been established in the literature. With regards to official debt, there are two effects working in opposite directions. Ceteris paribus, higher IFI debt in the current period implies higher total debt service in the following period. With high debt service in the following period, the sovereign is more likely to default on commercial debt to avoid low levels of consumption. This channel suggests that the higher the IFI debt, the higher the default probability on commercial debt. Second, positive IFI debt forces the sovereign to discount the future less and act more prudently lowering default probabilities. In this setting, we find that the first effect is quantitatively larger generating higher country spreads when the sovereign is indebted to the IFI as opposed to when it is not. 6

The elasticity of interest rates to official debt is lower than commercial debt. Higher commercial debt increases default probability significantly, as the benefit of default is the commercial debt that is forgiven. In the case of official debt, as mentioned above, higher official debt the current period increases total debt service in the following period, making the sovereign more likely to default to avoid low consumption levels. This channel is less direct. The sovereign internalizes the effect of its borrowing on interest rates and acknowledges these different elasticities, therefore, reallocates its portfolio in response to output shocks.

Our paper is closely related to the literature on sovereign debt, particularly emerging market debt that builds on the seminal work of Eaton and Gersovitz (1981). Recently, Arellano (2008) studied the quantitative implications of Eaton and Gersovitz's setup after introducing stochastic output and exclusion from capital markets for a period with stochastic length and direct output losses as punishment for default. This framework has also been extended to include trend shocks to output and debt renegotiation by Aguiar and Gopinath (2006) and Yue (2005), respectively. However, this literature overlooks the existence of IFIs in credit markets and the role they might play in the sovereign's debt

\footnotetext{
${ }^{5}$ In good times, countries may not have access to borrowing from an IFI. The IMF, for example, agrees to an SBA only when a country has balance of payments difficulties. To account for this, one can assume that IFI lending is available only when output falls below a certain level and the interest rates charged by the private sector creditors exceed a threshold. However, in equilibrium, these constraints would not be binding because the sovereign never chooses to borrow from the IFI if these conditions are not met.

${ }^{6}$ Note that we only establish correlation but not causality between spreads on commercial debt and IFI lending. In our setting, higher commercial spreads coupled with higher IFI lending are generated by negative endowment shocks which are the only underlying "cause" of fluctuations.
} 
and default decisions. To our knowledge, the only analysis in this area is conducted by Aguiar and Gopinath (2006) who analyze the implications of a third party bailout limited to a ratio of the defaulted debt. In their extension, this third party is not explicitly modelled and the bailout takes the form of a grant that is never repaid. In contrast, we explicitly model the third party as an international financial institution that lends with terms similar to SBAs of the IMF.

An incomplete list of other studies in the sovereign debt literature include Bai and Zhang (2005), Guimaraes (2006), Alfaro and Kanczuk (2007), Arellano and Ramanarayanan (2008), and Mendoza and Yue (2008). Alfaro and Kanczuk (2007) introduce international reserves into the standard strategic default model and allow the sovereign to smooth its consumption during autarky by using these reserves. This extension is similar to ours in the sense that it also brings in an additional instrument that is available during autarky periods. However, reserve holding is different in spirit because it has a lower bound of zero. With this lower bound, the authors find that it is optimal for the sovereign not to hold any reserves. With the discount rate much higher than the interest rate on reserves (as usually assumed in the sovereign debt literature), they conclude that zero reserve accumulation is optimal. On the contrary, in our setup, the sovereign is assumed to be a net debtor vis-a-vis the IFI, making it possible to obtain a well-defined stationary distribution for this type of debt.

Our modelling of different discount factors for the sovereign is reminiscent of the strategies used by Cole et. al (1995), Alfaro and Kanczuk (2005), Hatchondo, Martinez, Sapriza (2007) and D'Erasmo (2008) to model "patient vs. impatient" or "aligned vs. misaligned" governments using different discount factors. In other words, conditionality implies that the sovereign has to act as a patient/aligned type as long as it is indebted to the IFI. An important difference between our model and those utilized in the aforementioned studies is that in those models different types of governments alternate in power stochastically, while in ours, the sovereign in some sense chooses its type endogenously because we assume that the sovereign acknowledges that it has to act as a patient/aligned type as long as it is indebted to the IFI. And being indebted to the IFI is a choice made by the sovereign.

In our study, we abstract from any informational role that an IMF program might play and, as a result, from any catalytic effect that such a program might have. There is an extensive literature on this topic where the debate is centered around whether IMF lending helps countries avoid or mitigate crises by reducing domestic political costs of adjustment or whether it exacerbates moral hazard. Cottarelli and Giannini (2002) and Ghosh et. al. (2002) provide empirical evidence suggesting that IMF assistance leads to little increase in private sector flows, suggesting a minor catalytic role, if any. Mody and Saravia (2006) find that whether IMF programs provide a positive signal depends on the likelihood that these programs lead to policy adjustments. In the theoretical literature, Morris and Shin (2006) and Corsetti, Guimaraes, and Roubini (2006) analyze the conditions under which the catalytic role exists using a global games framework. Finally, Jeanne and Zettelmeyer (2004) study the effects of IMF assistance on debtor moral hazard. In our model, the IFI lends during exclusion from capital markets and serves as an alternative source of funding which the sovereign utilizes to avoid high interest rates in bad times. By modeling the IFI this way, we abstract from any catalytic effect.

Finally, there is a related literature analyzing the impact of IMF programs on countries' 
macroeconomic conditions. Eichengreen, Gupta and Mody (2006) provide a comprehensive survey of this literature and investigate potential links between sudden stops (severeness and probability) and IMF programs. The authors find that IMF programs somewhat reduce the incidence of sudden stops.

For the rest of the paper we take the International Monetary Fund (IMF) as the representative IFI and focus on the properties of its lending. The paper is organized as follows: Section II documents the institutional framework of IMF lending and the cyclical properties of IMF and private sector creditor lending for a set of emerging market economies. Section III describes the benchmark two creditor model. Section IV elaborates the solution, describes our calibration, reports model statistics comparing them with the data, and conducts a sensitivity analysis. Section V concludes.

\section{IMF Lending}

\section{A. Institutional Framework}

The IMF lends to member countries with balance of payments difficulties to provide them with temporary financing. ${ }^{7}$ Lending of the IMF involves "conditionality," that is, the borrower needs to follow appropriate policies to resolve the balance of payments problems. Conditionality is aimed at enabling the borrower to repay the IMF on time.

The amount borrowed from the IMF determines the level of conditionality as well as the interest rate. Borrowing up to 25 percent of quota involves essentially no conditionality. ${ }^{8}$ Any amount beyond the 25 percent threshold requires the borrower to propose a policy program described in a letter of intent, also called an IMF arrangement or program. IMF lending to provide funding in the face of balance of payments difficulties takes place under the General Resources Account which include the SBAs usually lasting 4-6 quarters with repayment in 3-5 years.

The interest rate associated with SBAs is the sum of the Special Drawing Rights (SDR) interest rate, margin, burden sharing adjustment, service fee, commitment fee and surcharges.

- SDR interest rate is a weighted average of the 3-month U.S. T-bill rate, 3-month UK T-bill rate, Japanese Government 13-week financing bills, and 3-month Eurepo rate.

- Margin is intended to cover the intermediation costs of the IMF and help build reserves against credit risk. It is set at the beginning of every fiscal year by the management of the IMF. The average from May 1993-September 2008 is 62 bps and it is currently set at 100 bps. $^{9}$

\footnotetext{
${ }^{7}$ There is also lending to low-income countries for poverty reduction. In this paper, we focus on emerging markets that borrow for balance of payments reasons and the types of loans that are available to them.

${ }^{8}$ Each member is assigned a quota when it enters the IMF. Quotas are largely based on the size of the country determining the voting power of countries and their borrowing limits.

${ }^{9}$ The margin was negative for 1981-May 1993 since the rate of charge was not based on the SDR rate and the imputed margin for that period is negative.
} 
- A charge for burden sharing is added to cover losses due to over-due obligations to the IMF. These charges are refunded as overdue obligations are repaid. The average of the burden sharing adjustment from May 1986-September 2008 is 19 bps and it is currently set at 2 bps.

- A service fee of 50 bps apply to cover part of the intermediation costs and this fee is paid at the time the loan is disbursed.

- A commitment fee is collected but refunded as the loans are withdrawn. ${ }^{10}$ This fee is 25 bps for loans up to the country's quota, and 10 bps for those in excess of the quota.

- In the case of SBAs, a surcharge of 100 bps apply to the portion of those loans that are greater than 200 percent of the country's quota, and 200 bps for the portion greater than 300 percent.

The sum of the SDR interest rate, margin, and burden sharing adjustment is called the adjusted rate of charge plotted in Figure 1 with historical averages reported in Table 1. Both in the table and the figure, the IMF's adjusted rate of charge is compared against U.S. government bonds with 2, 3, and 5-year maturities since under SBAs, the loans are repaid within 3-5 years. The averages for the IMF's adjusted rate of charge are in line with the yield on 3-year U.S. government bonds. This result is somewhat expected given that the SDR interest rate constitutes a significant portion of the adjusted rate of charge and the SDR rate itself is a weighted average of developed country T-bill rates with shorter maturities. Similarly, Jeanne and Zettelmeyer (2001) conclude that the IMF's non-concessional lending rates, which include SBAs, are comparable to the risk free rate.

Note that the adjusted rate of charge and the above mentioned fees do not vary across countries. The only loan or country specific component of interest rates associated with SBAs is surcharges. These are determined by the size of the loan compared to the country's quota but not by the riskiness of a sovereign.

Another important feature of IMF lending is conditionality. IMF program related conditions include macroeconomic and structural measures that fall under the core areas of IMF's expertise. According to IMF (2002a), these areas are “...macroeconomic stabilization, monetary, fiscal and exchange rate policies, including the underlying institutional arrangements and closely related structural measures, and financial system issues related to the functioning of both domestic and international financial markets." IMF (2002b) reports that about 34 percent of the structural measures were regarding the fiscal sector from 1994-1999 followed by financial sector and privatization related measures that constituted 16 and 14 percent of total measures, respectively.

\section{B. Cyclical Properties}

Although cyclical properties of commercial debt flows have been extensively studied in the literature, those of IMF lending have remained largely unexplored. In this section, we

\footnotetext{
${ }^{10}$ Therefore, commitment is with regards to borrowing from the IMF rather than repayment.
} 
examine these properties for a set of emerging market economies and document our findings in Tables 3, 4, and 5. We choose the countries in our sample based on quarterly GDP data availability and on whether the country had an IMF program in the last two decades. Table 2 reports the main business cycle statistics associated with commercial debt for comparison with IMF lending.

Table 2 establishes that commercial debt flows are procyclical, highly variable and, on average, most sovereigns in our sample appear to be highly indebted to private sector creditors. Net debt flows by private sector creditors data reported in Table 2 are annual and are from the World Bank's Global Development Finance Database (includes bonds, commercial banks, other debt to private creditors). Their standard deviations and correlations with the corresponding country's real GDP are reported in the third and fourth columns of the Table and the fifth column documents the mean commercial debt stock. On average, the correlation of net lending by private sector creditors with real output is 0.37 . This correlation is positive for all of the countries in the sample, lying between 0.14 (Peru) and 0.62 (Thailand and Turkey). The average standard deviation of this type of lending is 3.71 with Thailand being an outlier with a standard deviation of 10.10 percent. Finally, commercial debt stock is around 15 percent of annual GDP on average.

Contrary to lending by private sector creditors, IMF lending is countercyclical with an average correlation of -0.15 with output. ${ }^{11}$ Using quarterly data on the use of IMF credit from International Financial Statistics (IFS), the second column of Table 3 reveals that countercyclicality holds for all countries except Thailand (0.18). ${ }^{12}$ For the case of Thailand, this statistic may be uninformative since Thailand's average IMF debt to GDP ratio was only 0.14 percent in the period for which quarterly GDP data are available (1993-2006).

The standard deviation of IMF debt flows reported in the third column of the same table suggest that IMF debt flows are remarkably less variable than commercial debt flows $(1.22$ vs 3.71). Comparing the debt ratios, mean debt to the IMF is lower than that to the private sector creditors (16 vs. 6 percent). Also note that IMF debt ratios are calculated using quarterly GDP whereas debt to private sector creditors is divided by annual GDP which implies that IMF debt comparable with the 16 percent private sector creditor debt would be around 1.6 percent. Therefore, on average, IMF debt is around one tenth of private sector creditor debt. ${ }^{13}$

Table 4 reports statistics on the relationship between the use of IMF resources and country spreads based on J.P. Morgan's EMBI Global spread data from Bloomberg. Since the first observation of spread data varies across countries, we report in the second column of the table, the periods considered in the calculations. The following two columns compare the average EMBI spreads for periods when there was positive use of Fund

\footnotetext{
${ }^{11}$ The finding, that in bust periods a country is more likely to have an IMF program, is not to say that one causes the other. Correlation does not imply causality.

${ }^{12}$ Real GDP series are also from IFS. They are logged, deseasonalized using Census X12, and HP filtered with smoothing parameter 1600. Availability of quarterly GDP data differs among countries, therefore we report in Table 3 the periods considered for each country.

${ }^{13}$ These results are in line with Ratha (2001) who finds that during 1996-1998, private flows to developing countries were 10-12 times multilateral flows.
} 
resources with those when the country was not using Fund resources. The number of observations are reported in parenthesis.

Note that of the available sample of EMBI data, only Mexico and Thailand had a significant number of periods with and without use of Fund resources. For both of these countries spreads in periods with use of Fund credit are about 3 times the spreads in periods without Fund credit. All other countries were indebted to the IMF during a significant portion of the sample period. We find average spreads to be 617 (199) bps when Mexico (Thailand) was using Fund resources, while the average spreads were 242 (61) bps when it was not. Suspecting that the spread data might have outliers during crises, we also calculate median spreads and find these to be 488 (163) bps in periods when Mexico (Thailand) was indebted to the IMF versus 214 (58) bps when it was not. Finally, we compute the correlation between spreads and a dummy variable that is set equal to 1 when the country is indebted to the IMF. We find this correlation to be positive for all countries in our sample except Ecuador with an average of $0.48 .{ }^{14}$

These results on the relationship between spreads and IMF borrowing appear to be in line with those of Mody and Saravia (2006). Mody and Saravia (2006) find that spreads on bonds issued during an IMF arrangement are higher. The authors collect data on launch spreads for more than 3,000 emerging market and developing country bonds and separate them based on whether they were issued during an IMF program or not. Their calculations reveal that the spreads during IMF programs were 406, while they were 223 in the absence of programs.

IMF borrowing displays lumpiness in the sense that it spikes after a country enters an arrangement with the IMF. These periods of high borrowing are nested in periods without any borrowing from the IMF. This kind of pattern manifests itself as a higher standard deviation of net IMF flows relative to another series with a smoother pattern. In addition to the standard deviation already reported in Table 3, we also calculate the probability of positive use of IMF resources from its GRA account $\left(\operatorname{Pr}\left[d^{*}>0\right]\right)$ to get a sense of the average length of periods with and without IMF borrowing. Table 5 documents that the unconditional probability of having an arrangement with the IMF is 46 percent for 1945-2007 and 55 percent for 1970-2007 when we expand our sample to 17 emerging market economies. The rationale for expanding our sample for this exercise is to get a more unbiased picture because one of our selection criteria for the initial sample was to include countries with significant IMF borrowing in the last several decades. So by construction, the probability of the use of IMF credit would be biased upwards. The additional countries included in the calculation of the mean reported in the last row of Table 5 are Chile, Colombia, Egypt, India, Korea, Malaysia, Singapore, and Venezuela. Note that these probabilities are higher for our original sample with 9 countries. ${ }^{15}$

Essentially, all IMF loans to major emerging market economies have been repaid.

\footnotetext{
${ }^{14}$ Averages reported in the last row for $E\left[s \mid d^{*}>0\right]$ and $E\left[s \mid d^{*}=0\right]$ are weighted by the number of observations. The average for $\rho\left(I_{d *>0}, s\right)$ includes only those countries with at least 4 observations without use of Fund credit (Argentina, Brazil, Mexico, and Thailand).

${ }^{15}$ Barro and Lee (2005) calculate the fraction of time that a country had an IMF loan program (SBA or EEF) to be 0.185 percent using data for 130 countries from 1975-1999. They also calculate the IMF loan approval frequency to be 0.364 . Approval frequency is calculated by assigning ' 1 ' if the country had a loan approved within a 5-year interval. Our numbers differ from theirs mainly because we focus only on large emerging market economies and also our dummy is based on quarterly data rather than 5-year intervals.
} 
Zettelmeyer (2005) indicates: "In the past, the IMF has virtually always been repaid, but this leaves the possibility that currently open lending relationships may eventually result in arrears or debt forgiveness." Jeanne and Zettelmeyer (2001) find that "most open lending relationships with emerging market countries are statistically similar to past lending cycles that eventually ended in repayment while the very long open lending cycles of many poor countries statistically 'look' like they might continue forever." Similarly, Eichengreen (2003) and Saravia (2004) argue that the IMF loans are typically repaid. Only during the debt crises of the 1980s, was there an increase in non-repayment cases. According to Zettelmeyer (2005), there were 13 countries in protracted arrears to the IMF. ${ }^{16}$ However, most of these countries have repaid and in particular Peru has repaid which is the only emerging market among these countries.

To summarize, this section establishes that:

- The IMF lending rate under SBAs can be approximated by the sum of the risk free rate and a charge that increases with the amount borrowed.

- Lending by private sector creditors is procyclical whereas IMF lending is countercyclical.

- Debt to the private sector creditors is about three times more variable than that to the IMF.

- The average debt stock to the IMF is about one tenth of the debt to private sector creditors.

- Country spreads are higher in periods when countries are indebted to the IMF.

- The unconditional probability of the use of IMF resources is about 50 percent for emerging markets.

- IMF has almost always been repaid particularly by emerging market economies.

\section{Model}

The model features competitive, risk-neutral private sector creditors, an IFI, and a sovereign that maximizes the utility of its households. The model mainly builds on the work of Eaton and Gersovitz (1981) on sovereign debt with potential repudiation. The distinguishing and appealing feature of this framework is the lack of commitment of the sovereign to repaying its debt. Due to this commitment problem, the sovereign may optimally default on its debt to the private sector creditors. Therefore, this model analyzes a "willingness to pay" scenario rather than "ability to pay."

Every period, the sovereign is in one of two states: default or non-default vis-a-vis the private sector creditors, $D, N$. If it starts in the non-default state, the sovereign has access to borrowing commercially. In these non-default states, it observes its output level,

\footnotetext{
${ }^{16}$ Cambodia, Guyana, Haiti, Honduras, Liberia, Panama, Peru, Sierra Leone, Somalia, Sudan, Vietnam, Zaire, and Zambia.
} 
makes a decision on whether to default or not, and also whether to borrow from the IFI. If it chooses to default, it does not repay its existing debt, but as a punishment, it loses access to commercial borrowing for a period with exogenously and stochastically determined length. If it does not default, however, it repays its debt obligations in full, chooses how much to borrow commercially and from the IFI, and maintains the option to default in the following period. During exclusion from commercial borrowing, the sovereign only chooses whether to borrow from the IFI based on its output remaining after incurring losses due to default.

The IFI lends to the sovereign at the risk free rate plus a debt elastic component that is intended to capture the surcharges of the IMF. ${ }^{17}$ The sovereign does not face a commitment problem in repaying its debt to the IFI because of the preferred creditor status of the IMF and also the observation that major emerging market economies have almost always repaid their debt to the IMF. There is only one IFI with a non-profit role as an international financial institution in this context.

In our setup, the existence of the IFI provides the sovereign with an additional instrument to smooth consumption that is available even during exclusion from commercial credit markets. Borrowing from the IFI is preferable in times when the default probability on private sector debt is high (and as a result the interest rate is high) or when the sovereign is in default and does not have access to commercial credit markets at all.

The sovereign makes its default decision in the following fashion:

$$
V\left(d, d^{*}, y\right)=\max _{D}\left\{V^{D}\left(d^{*}, y\right), V^{N}\left(d, d^{*}, y\right)\right\}
$$

where $D$ is the binary variable that represents the decision to default $(D=1)$ or not $(D=0), y$ is output as explained below, and $d$ and $d^{*}$ denote the debt stock to private sector creditors and the IFI, respectively. Note that the value of default, $V^{D}$, depends on output and IFI debt because the level of commercial debt becomes irrelevant when it is not repaid. However, the value of non-default, $V^{N}$, and the decision on whether to default or not, $D$, depend on the level of debt to IFI and commercial debt, as well as output. $D=1$ (default) is chosen if and only if $V^{D}>V^{N}$. For state $\left(d^{*}, y\right)$ the value of default can be expressed as:

$$
V^{D}\left(d^{*}, y\right)=\max _{d^{* \prime}}\left\{u(c)+\beta\left(d^{* \prime}\right) \sum_{y^{\prime}}\left[\theta V\left(0, d^{* \prime}, y^{\prime}\right)+(1-\theta) V^{D}\left(d^{* \prime}, y^{\prime}\right)\right] \pi\left(y^{\prime} \mid y\right)\right\}
$$

where $u$ is CRRA per-period utility, $u(c)=\frac{c^{1-\sigma}}{1-\sigma}, c$ is consumption, and $\beta\left(d^{* \prime}\right)$ is the discount factor elaborated further below. ${ }^{18}$ An implicit assumption in this formulation is that once the country regains access to commercial borrowing, all of its commercial debt is forgiven and it starts with $d=0 . \theta$ is the exogenously determined probability of entry to the credit market after default, therefore, it gives the average duration of exclusion once the sovereign defaults. The budget constraint during exclusion is

$$
y^{d e f}=c+d^{*}-q^{*} d^{* \prime}
$$

\footnotetext{
${ }^{17}$ As discussed in Section 2, the rate applied by the IMF includes a surcharge determined by the amount borrowed.

${ }^{18}$ Throughout the paper, primes refer to the following period.
} 
where $q^{*}$ is the price of IFI debt which can be written as:

$$
q^{*}\left(d^{* \prime}\right)=\frac{1}{1+r+\phi\left(d^{* \prime}\right)} .
$$

Note that this price depends only on $d^{* \prime}$ and not on $d^{\prime}$ or $y$.

Output is exogenous and is characterized by an $\mathrm{AR}(1)$ process:

$$
y=e^{z}
$$

where $z_{t}=\rho z_{t-1}+\epsilon_{t}$ and $\epsilon \sim N\left(0, \sigma_{z}^{2}\right)$. We approximate this Normal process with a Markov chain with $S$ states and transition probability matrix $\pi . \pi\left(y_{j} \mid y_{i}\right)$ denotes the probability of transiting from state $i$ to $j$.

The output process is truncated during default as in Arellano (2008) in order to bring the default probability implied by the model in line with those in the data. We assume that the direct output cost of default increases with output. In other words, if a country defaults when its output is high, the output loss due to the default decision would be higher as opposed to a sovereign that defaults when its output is low. Mathematically:

$$
y^{d e f}= \begin{cases}y, & \text { if } y<\hat{y} \\ \hat{y}, & \text { if } y>\hat{y}\end{cases}
$$

In non-default periods, the sovereign decides whether or not to default, and how to allocate its financing needs among the private sector creditors and the IFI. The value of non-default in this setup can be written as:

$$
V^{N}\left(d, d^{*}, y\right)=\max _{d^{\prime}, d^{* \prime}}\left\{u(c)+\beta\left(d^{* \prime}\right) \sum_{y^{\prime}} V\left(d^{\prime}, d^{* \prime}, y\right) \pi\left(y^{\prime} \mid y\right)\right\}
$$

subject to the budget constraint:

$$
c=y-d+q d^{\prime}-d^{*}+q^{*} d^{* \prime} .
$$

As mentioned above, the risk neutral and perfectly competitive private sector creditors lend at a rate that is mainly determined by the default probability of the sovereign. The commercial bond price schedule is given by:

$$
q\left(d^{\prime}, d^{* \prime}, y\right)=\frac{1-E\left[\lambda\left(d^{\prime}, d^{* \prime}, y\right)\right]}{1+r} .
$$

and the spread is defined as $s=1 / q-1-r$.

In order to capture the conditionality of IMF loans, and also to account for the regularity that sovereigns do not borrow from the IMF every period as documented in Table 5, we assume that the sovereign has to switch to a higher discount factor, that is, a lower discount rate as long as it is indebted to the IFI. Models of sovereign default have traditionally calibrated discount rates such that they are significantly greater than the risk free interest rate. In this fashion, more realistic debt ratios and default probabilities were achieved because, with a low discount factor, the sovereign has a strong desire to consume 
today and is willing to hold larger amounts of debt in the long run. By assuming that borrowing from the IFI is associated with a higher discount factor, we are building "more prudent" policies that come with conditionality. This can also be interpreted as a reduction in consumption (public consumption in particular) that typically is part of conditionality. More formally:

$$
\beta\left(d^{* \prime}\right)= \begin{cases}\beta^{H}, & \text { if } d^{* \prime}>0 \\ \beta^{L}, & \text { if } d^{* \prime}=0\end{cases}
$$

The competitive equilibrium of this economy is characterized by price schedules for commercial debt, $q\left(d^{\prime}, d^{* \prime}, y\right)$ and official debt, $q^{*}\left(d^{* \prime}\right)$, debt and consumption allocations , $d^{\prime}\left(d, d^{*}, y\right), d^{* \prime}\left(d, d^{*}, y\right)$, and $c\left(d, d^{*}, y\right)$ such that:

1. The sovereign maximizes its utility subject to the budget constraint taking the price schedules as given.

2. Given the default probabilities implied by the debt position of the sovereign, private sector creditors lend at price $q\left(d^{\prime}, d^{* \prime}, y\right)$, and the IFI lends at $q^{*}\left(d^{* \prime}\right)$ to the sovereign.

3. The goods market clears.

\section{Quantitative Analysis}

\section{A. Solution}

In this setting with two types of creditors, the sovereign not only makes default decisions but also faces a portfolio allocation problem in non-default periods. Depending on the realizations of output and its current level of debt to each type of creditor, the sovereign allocates its borrowing needs. Given that these creditors lend at different terms, we can solve the sovereign's portfolio choice problem using standard techniques explained below.

Initially, we solve for the competitive equilibrium of the model with state spaces of $d$ and $d^{*}$ spanning a wide interval. We find that commercial debt has a well-defined stationary distribution in the interval $[0.30,0.82]$ and $d=0$ is imposed in default periods. This reveals that any commercial debt level in the $(0,0.30)$ range is not optimal. We use this observation to "economize" on the nodes. We place $(N B-1)$ equally spaced nodes in the $[0.30,0.82]$ interval, $\left\{d_{1}, d_{2}, d_{3}, \ldots, d_{N B-1}\right\} \in[0.30,0.82]$ and concatenate them with $\left\{d_{N B}\right\}=\{0\}$. The ergodic distribution of IFI debt also displays such discontinuity, however, it is not as strong as the one for commercial debt. Therefore, we set the state space for $d^{*}$ to span the interval $[0,0.14] .{ }^{19}$

In order to find the equilibrium allocations and price schedule for private sector debt, we implement the following algorithm:

\footnotetext{
${ }^{19}$ Note that by limiting the lower limit of IFI debt to be zero, we assume that the sovereign cannot lend to the IFI. In practice, some countries in particular advanced economies can be creditors to the IMF. With our calibration, even if the sovereign is allowed to be a creditor, it would never choose to do so in the model. We consider this a plausible scenario given our focus on emerging market economies.
} 
1. Discretize the state space as explained above.

2. Conjecture a price schedule for private sector debt, $q^{\text {old }}\left(d^{\prime}, d^{* \prime}, y\right)=\frac{1}{1+r}$.

3. Solve the sovereign's problem recursively using value function iteration by taking the conjectured price schedule for private sector debt and the IFI debt price schedule as given and obtain default decisions $D\left(d, d^{*}, y\right)$, policy functions $d^{\prime}\left(d, d^{*}, y\right)$, $d^{* \prime}\left(d, d^{*}, y\right)$, and $c\left(d, d^{*}, y\right)$.

4. Given these policy functions, calculate default probability $\lambda\left(d^{\prime}, d^{* \prime}, y\right)$.

5. Using the default probability $\lambda\left(d^{\prime}, d^{* \prime}, y\right)$, calculate a new price schedule, $q^{\text {new }}\left(d^{\prime}, d^{* \prime}, y\right)=\frac{1-E\left[\lambda\left(d^{\prime}, d^{* \prime}, y\right)\right]}{1+r}$.

6. Update the conjectured price schedule $q^{\text {old }}\left(d^{\prime}, d^{* \prime}, y\right)$ with a weighted average of $q^{\text {old }}\left(d^{\prime}, d^{* \prime}, y\right)$ and $q^{\text {new }}\left(d^{\prime}, d^{* \prime}, y\right)$. Repeat these steps until convergence is obtained, that is, $\max \left|q^{\text {old }}\left(d^{\prime}, d^{* \prime}, y\right)-q^{\text {old }}\left(d^{\prime}, d^{* \prime}, y\right)\right|<\xi$ where $\xi$ is a very small number. ${ }^{20}$

Note that Hatchondo, Martinez, Sapriza (2007) need to keep track of the government type as a state variable and evaluate different continuation values for different types. In our setting, sovereign essentially chooses its own type and the information with regards to its type can be inferred from its debt to the IFI making it unnecessary to include it as a separate state variable.

\section{B. Calibration and Data}

We have three sets of parameters, those borrowed from the sovereign debt literature, those estimated from data and those calibrated to match certain model statistics to the data. All parameters are reported in Table 6 .

The risk aversion coefficient and risk free rate are standard both in the sovereign debt and small open economy business cycle literatures. Following Arellano (2008) and Aguiar and Gopinath (2006), we set the probability of redemption to 10 percent, implying an average exclusion of 10 periods (2.5 years with quarterly calibration).

We estimate the parameters governing the output process using quarterly Argentine GDP data for the two decades before its default (1980Q1-2000Q4) obtained from Neumeyer and Perri (2005). ${ }^{21}$ The GDP series is deseasonalized, logged and HP filtered with smoothing parameter 1600. With our notation of $y=e^{z}$ where $z_{t}=\rho z_{t-1}+\epsilon_{t}$ and $\epsilon \sim N\left(0, \sigma_{z}^{2}\right)$, we estimate an $\operatorname{AR}(1)$ process and find $\rho=0.91$ and $\sigma_{z}=0.019$. With these $\operatorname{AR}(1)$ parameters, we estimate a Markov process with 9 states using Tauchen's algorithm.

The discount factor $\beta^{L}$ and $\hat{y}$ are set to match the default frequency. We assume $\phi$ is linear, $\phi\left(d^{* \prime}\right)=k d^{* \prime}$. The parameters that are specific to this model are the debt elasticity

\footnotetext{
${ }^{20}$ Note that the calculation of $q^{*}$ does not require solving for a fixed point. For given $\phi\left(d^{* \prime}\right)$, we evaluate $q^{*}\left(d^{* \prime}\right)$ and plug in the budget constraint of the sovereign.

${ }^{21}$ Similarly, we report model statistics for pre-default periods to make them comparable with the data. However, for those statistics regarding borrowing from the IFI, we include the default periods both in the data and in the model. This is to capture IFI borrowing dynamics during default as well.
} 
of the IFI interest rate, $k$, and the discount factor when indebted to the IFI, $\beta^{H}$. We set $k$ to match mean IFI debt and $\beta^{H}$ to match the probability of the use of IMF credit.

Argentine business cycle statistics are reported in the first column of Table 7 . We use the same series on private sector creditor debt and IMF lending as in Section 2. Since private sector creditor debt data is annual, simulated data related to borrowing from private sector creditors reported in the second and third columns of the same table are also annualized to facilitate comparison. The number of defaults is calculated based on Reinhart, Rogoff, and Savastano (2003) who report that Argentina defaulted 4 times in the period 1824-1999. Adding the most recent default episode in 2001, we have 5 defaults in 183 years which translates into roughly 70 defaults per 10,000 quarters.

\section{Findings}

Existing sovereign debt models with only private sector creditors establish that a high level of debt strengthens the incentives to default because the gain from default is the amount of debt that is forgiven. ${ }^{22}$ Conversely, a high output realization strengthens repayment incentives as the sovereign can afford to repay without facing low levels of consumption. These effects are present in the two creditor model as well as those that arise due to the introduction of the IFI.

The default probability on commercial debt increases with the level of IFI debt although not as fast as it does with commercial debt. This is evident in the price schedule plotted in Figure 2. The pricing schedule is steep suggesting that small increases in $d^{\prime}$ increase interest rates significantly, however, the interest rate difference between high and low levels of $d^{* \prime}$ is not large. The steepness is intuitive given that commercial debt is directly linked to the benefit of default. For the case of IFI debt, there are two effects working in opposite directions. First, since IFI debt is not defaultable, a high level of it implies a higher IFI debt service in the following period leaving the sovereign with less resources to repay commercial debt. This channel suggests that the higher the IFI debt, the higher the default probability on commercial debt. Second, positive IFI debt forces the sovereign to discount the future less and act more prudently lowering default probabilities. As suggested by Figure 2, the first effect is quantitatively larger leading to commercial interest rates that increase with IFI debt.

Introduction of two different discount factors generates a fixed cost-like effect making it possible for the model to account for occasional IFI borrowing. When output is not low, the sovereign prefers $d^{*}=0$ keeping the discount factor low. However, when output is low, the sovereign chooses relatively high values of $d^{*}$. Therefore, small but positive values for $d^{*}$ are almost never optimal. These dynamics allow us to match the lumpiness and probability of use of Fund credit in the data. To ensure that these fixed cost-like effects are in fact due to the introduction of two different discount factors, we strip out the other ingredients of the model and analyze a simple small open economy consumption-savings setting explained in the Appendix. The aforementioned effect is present in that simple model confirming our intuition.

\footnotetext{
${ }^{22}$ See Arellano (2008), and Aguiar and Gopinath (2006) for a discussion of the equilibrium, solution and implications of models with one type of creditors.
} 
The model performs well in matching the non-target moments. Those moments related to IFI borrowing that are not used in the calibration exercise are the standard deviation of IFI debt flows, $\sigma\left(\Delta d^{*} / y\right)$, the correlation of these flows with output, $\rho\left(\Delta d^{*} / y, y\right)$, and the correlation of IFI debt dummy with spreads, $\rho\left(I_{d^{*}>0}, s\right)$. In addition to the model doing a good job in accounting for these statistics (perhaps with the exception of the standard deviation of flows that appear to be higher in the model compared to the data), it matches well those statistics related to commercial debt flows.

The weak countercyclicality of IFI debt is due to the decoupling of the interest rate charged by the IFI from default probability. The sovereign makes debt allocation decisions in non-default periods by comparing the cost of borrowing commercially and the cost of IFI debt. The cost of borrowing commercially increases when the economy is hit by a negative output shock. However, the cost associated with IFI debt does not depend on the realizations of these shocks. As a result, the sovereign chooses to hold less commercial and more official debt in its portfolio in bad times, $\left(\rho(\Delta d / y, y)=0.28, \rho\left(\Delta d^{*} / y, y\right)=-0.07\right)$. The weak countercyclicality result survives in the case of 'no conditionality' (see sensitivity results) suggesting that this result is related to the inelasticity of the IFI interest rate to output shocks and to the level of commercial debt rather than the modelling of two different discount factors.

The model generates a standard deviation of 2.98 percent for IFI debt flows, higher than that in the data (1.34). The relatively high variability for IFI debt flows leads the model to generate higher trade balance variability than that in the data. This is partly driven by the fact that in order to match the 60 percent probability of positive use of Fund resources, we introduce two discount factors that create dynamics similar to having a fixed cost. Therefore, the sovereign does not choose small but positive values of $d^{*}$. We observe similar dynamics in the data but not as strong as in the model. In other words, in the data, small but positive values of $d^{*}$ are chosen more often creating a discrepancy between the model and data with regards to the standard deviation of trade balance and IFI debt flows.

The model performs particularly well in matching the correlation between the Fund credit use dummy and spreads ( 0.22 in the data vs 0.25 in the model). In addition, in the model, spreads in periods with $d^{*}>0$ are 2.8 times those when $d^{*}=0$. This is in line with the data documented in Section 2. For Mexico and Thailand, this ratio is 2.55 and 3.25, respectively. For Argentina, $E\left[s \mid d^{*}>0\right]$ is as high as 2100 bps which is driven by a few outliers in the data. The ratio of median spreads conditional on being and not being indebted to the IMF is 2.32 , fairly close to the result generated by the model.

The shift in sovereign's portfolio towards IFI debt in response to a negative output shock does not suffice to reduce spreads. ${ }^{23}$ As mentioned above, any type of debt, official or commercial, leads to higher interest rates. However, the interest rates are much more elastic with respect to commercial debt than IFI debt. Given a certain level of total debt, a portfolio with only commercial debt leads to higher spreads than one that includes some IFI debt.

To further compare model implications with the data, we analyze the behavior of IFI debt

\footnotetext{
${ }^{23}$ This is not to say that the existence of the IFI leads to higher spreads. We conjecture that spreads would have been even higher in absence of the IFI borrowing and portfolio reallocation of the sovereign.
} 
in high and low spread periods. Table 8 reports average IFI debt when spreads are above their $75^{\text {th }}$ percentile, below their $25^{\text {th }}$ percentile, and finally when the sovereign is in default. This exercise allows us to assess model performance in yet another dimension that is not captured by the business cycle statistics.

The statistics implied by the model are reasonably close to the data. The model generates a mean IFI debt stock of 3.04 (2.98) percent when spreads are high (low). These are somewhat higher than those implied by the data (2.05 and 1.96). However, note that the difference in mean IFI debt between high and low spreads are close to data. Average IFI debt during default is 7.52 percent in the model, remarkably close to that in the data (7.97).

Finally, we conduct a similar exercise looking at the mean IFI debt during booms and busts defined as periods when endowment falls at least one standard deviation and periods when it exceeds its mean by at least one standard deviation, respectively. The model does a reasonably good job in generating a mean IFI debt during busts (5.79) that is significantly higher than that during booms (0.83). In the data, these mean IFI debts are somewhat higher than those generated by the model with 8.55 percent during busts and 1.53 percent during booms.

\section{Sensitivity Analysis}

Our sensitivity analysis focuses on the parameters that govern the cost of IFI borrowing, which we could not estimate from the data. In this section, we present four sets of results with different levels of conditionality and values for $k$, the parameter that governs the elasticity of the IFI interest rate with respect to the level of IFI debt. We compare these sets of results to the baseline scenario and find that our main results (weak countercyclicality of IFI debt flows and higher spreads when indebted to the IFI) are robust.

Table 10 presents business cycle statistics of the aforementioned scenarios. The first column reproduces the results with baseline parametrization to facilitate comparison. The second column reports those with no conditionality, that is, $\beta^{H}=\beta^{L}=0.884$. Without conditionality, the average official debt holdings increase from 3.27 to 3.55 with frequency of $d^{*}>0$ increasing from 65 percent to 90 percent. The other statistics do not change significantly except $\rho\left(I_{d^{*}>0}, s\right)$ and $\sigma\left(\Delta d^{*} / y\right)$. As one would expect, the result that IFI debt is chosen to avoid high levels of interest rates somewhat weakens. This is evident in the fact that some IFI debt is almost always chosen, and also because the positive correlation between the IFI debt dummy and spreads is lower. Lower variability of IFI debt flows is also an outcome of the no conditionality scenario as IFI debt is chosen more frequently, with fewer "jumps" to $d^{*}=0$ reducing the overall standard deviation of IFI debt flows.

The higher conditionality scenario reported in the third column largely works in the opposite direction compared to the no conditionality scenario. The average IFI debt levels and frequency of IFI borrowing are lower while the variability of IFI debt flows are higher. An interesting implication of this scenario is a higher number of defaults (73 vs 70 in 
baseline). The sovereign can less effectively use IFI debt to avoid costly default when conditionality attached to it is higher.

Increasing $k$ changes the moments in a similar way to the high conditionality scenario by reducing average IFI debt and its frequency. The differences between these two scenarios are their implications for default probabilities and variability of IFI debt flows. While the high conditionality scenario implies that a wider range of small $d^{*} \mathrm{~s}$ is not chosen, the high $k$ scenario does not have this implication. It simply leads to lower IFI debt holdings as well as a smoother pattern for its flows.

The fifth and last column of Table 10 reports the statistics of the scenario with a lower $k$. Contrary to the higher $k$ scenario, average IFI debt and frequency of IFI borrowing are higher than baseline. Moreover, in this scenario, the number of defaults is higher from which we can conclude that increasing the variable costs associated with IFI debt can help reduce the incidence of default while increasing conditionality works in the opposite direction.

\section{Conclusion}

This paper proposed a framework for analyzing dynamics of lending by IFIs in international credit markets. This framework sheds light on the decisions of a sovereign borrower regarding when to default on its commercial debt in the existence of an IFI and how to allocate its borrowing needs among these two types of creditors.

Differences in the contracts offered by private sector creditors and IFIs take us a long way in accounting for the stark differences in cyclical properties of these two types of debt. Characteristics of IFI lending are modelled based on the institutional framework of IMF's Stand-by Arrangements. The interest rate charged does not depend on the sovereign's riskiness but only on the size of the loan. In addition, as long as the sovereign is indebted to the IFI, it has to follow more prudent policies, modelled as the sovereign acting as if it has a higher discount factor, valuing future consumption more than it does without any IFI debt. The model successfully accounts for the weak countercyclicality of IFI debt flows as well as the fact that the IFI debt stock tends to be higher in times of high spreads. These findings are shown to be robust to some of the key parameters.

The recent increase in demand for IMF loans by emerging market economies underscores the importance of understanding the dynamics of IMF lending and its impact on a sovereigns' decisions. In addition to providing a setting that accounts for key regularities in the data, the model laid out in this paper can be utilized to answer policy questions regarding the design of IMF lending facilities. The current setting mimics SBAs, however, one could model other facilities such as the new short term lending facility, and compare their implications on debt and default. In addition, our model could be used to study the dynamics of the demand for IMF lending as well as normative questions regarding the relevance of the IMF. 


\section{Appendix: Simple Small Open Economy Model}

In this section we analyze a simple small open economy model to elaborate further the implications of switching to a higher discount factor when in debt. We solve the following model with a constant interest rate assuming that commitment technology exists, so there is no default. In order to simplify the analysis further and increase the accuracy of the results, we assume there is only one lender that lends at the risk free rate. However, whenever the country borrows from this creditor, it has to switch to a higher discount factor. Similar to our benchmark model, we assume an endowment economy but with an i.i.d. exogenous stochastic process. More formally, the small open economy would solve:

$$
\max _{c_{t}} E_{0} \sum_{t=0}^{\infty} \beta\left(b_{t+1}\right)^{t} u\left(c_{t}\right)
$$

subject to

$$
c_{t}+b_{t+1}=y_{t}+b_{t}(1+r)
$$

$b$ denotes bond holdings, $y$ is endowment, and interest rate $r$ is assumed to be constant. We assume a CRRA utility function and set $\beta(1+r)<1$ to ensure stationarity for bonds. This is a standard consumption-saving problem in the case of a small open economy except that the lender requires the economy to switch to a different discount factor as a condition for lending:

$$
\beta(b)= \begin{cases}\beta^{H}, & \text { if } b<0 \\ \beta^{L}, & \text { if } b=0\end{cases}
$$

This specification for the discount factor is the same as that in our benchmark two creditor model with default.

Figure 3 plots the stationary distributions for two parameterizations of this model, a baseline parameterization with $\beta^{H}=\beta^{L}=0.98$ and one with different discount factors $\beta^{H}=0.98, \beta^{L}=0.979965$. All other parameters were kept the same with the standard deviation of output set to 4.5 percent. We set $\beta^{L}$ such that $b^{\prime}<0$ is chosen around 60 percent of the time, again similar to our benchmark model.

We find that one needs to set $\beta^{H}-\beta^{L}$ to a very low number in order to obtain the 60 percent probability of a negative bond position. Larger differences between the two discount factors quickly lead to the country choosing autarky as opposed to borrowing and switching to a higher discount factor. This is likely to be a result of the fact that in these models, the welfare cost of living in autarky is small.

Having to switch to a higher discount factor leads the country not to choose negative but small (in absolute value) bond positions. Instead of borrowing a small amount, it becomes optimal not to borrow at all and stay in the low discount factor. This is evident in Figure 3 which reveals that bond positions in the interval $[-0.04,0]$ are almost never chosen. 


\section{References}

Aguiar, Mark and Gita Gopinath, 2006, "Defaultable Debt, Interest Rates and the Current Account," Journal of International Economics, vol. 69, pp. 64-83.

Alfaro, Laura and Fabio Kanczuk, 2005, "Sovereign Debt as a Contingent Claim: A Quantitative Approach," Journal of International Economics, vol. 65, pp. 297-314.

Alfaro, Laura and Fabio Kanczuk, 2007, "Optimal Reserve Management and Sovereign Debt," Harvard Business School working paper, No. 07-010.

Arellano, Cristina, 2008, "Default Risk, the Real Exchange Rate and Income Fluctuations in Emerging Economies," American Economic Review, vol. 98, pp. 690-712.

Arellano, Cristina and Ananth Ramanarayanan, 2008, "Default and the Term Structure in Sovereign Bonds," University of Minnesota mimeo.

Bai, Yan and Jing Zhang, 2005, "Financial Integration and International Risk Sharing," University of Minnesota mimeo.

Barro, Robert J. and Jong-Wha Lee, 2005, "IMF Programs: Who is Chosen and What are the Effects?," Journal of Monetary Economics, 52, pp. 1245-1269.

Cole, Harold , James Dow, and William B. English, 1995, "Default, Settlement and Signalling: Lending Resumption in a Reputational Model of Sovereign Debt," International Economic Review, 36, pp. 365-385.

Corsetti, Giancarlo, Bernardo Guimaraes, and Nouriel Roubini, 2006, "International Lending of Last Resort and Moral Hazard: A Model of IMF's Catalytic Finance," Journal of Monetary Economics, 53, pp. 441-471.

Cottarelli, Carlo and Curzio Giannini, 2002, "Bedfellows, Hostages, or Perfect Strangers? Global Capital Markets and the Catalytic Effect of IMF Crisis Lending," IMF Working Paper No. 02/193.

D'Erasmo, Pablo, 2008, "Government Reputation and Debt Repayment in Emerging Economies," University of Maryland mimeo.

Eaton, Jonathan and Mark Gersovitz, 1981, "Debt with Potential Repudiation," Review of Economic Studies, vol. 48, pp. 289-309.

Eichengreen, Barry, 2003, "Restructuring Sovereign Debt," Journal of Economic Perspectives, vol. 17, pp.75-98.

Eichengreen, Barry, Poonam Gupta, and Ashoka Mody, 2006, "Sudden Stops and IMF-Supported Programs," NBER Working Paper No. 12235.

Ghosh, A., T. Lane, M. Shulze-Ghattas, A. Bulir, J. Hamman, and A. Mourmouras, 2002, "IMF Supported Programs and Capital Account Crises," IMF Occasional Paper No. 210. 
Guimaraes, Bernardo, 2006, "Optimal External Debt and Default," London School of Economics mimeo.

Hatchondo, Juan Carlos, Leonardo Martinez and Horacio Sapriza, 2007, "Heterogeneous Borrowers in Quantitative Models of Sovereign Default," International Economic Review, forthcoming.

International Monetary Fund, 2002a, "Guidelines on Conditionality."

International Monetary Fund, 2002b, "The Modalities of Conditionality - Further Considerations."

Jeanne, Olivier, and Jeromin Zettelmeyer, 2001, "International Bailouts, Moral Hazard and Conditionality," Economic Policy, pp. 409-432.

Jeanne, Olivier, and Jeromin Zettelmeyer, 2004, "The Mussa Theorem (and Other Results on IMF Induced Moral Hazard)," IMF Working Paper 04/192.

Mendoza, Enrique, and Vivian Yue, 2008, "A Solution to the Default Risk-Business Cycle Disconnect," NBER Working Paper No. 13861.

Mody, Ashoka, and Diego Saravia, 2006, "Catalyzing Capital Flows: Do IMF Supported Programs Work as Commitment Devices?," The Economic Journal, vol. 116, pp.843-867.

Morris, Stephen, and Hyun Song Shin, 2006, "Catalytic Finance: When Does it Work?," Journal of International Economics, vol. 70, issue 1, pp.161-177.

Neumeyer, Pablo, and Fabrizio Perri, 2005, "Business Cycles in Emerging Economies: The Role of Interest Rates," Journal of Monetary Economics, vol. 52, issue 2, pp.345-380.

Ratha, Dilip, 2001, "Complementarity Between Multilateral Lending and Private Flows to Developing Countries," World Bank Policy Research Working Paper 2746.

Reinhart, Carmen, Kenneth Rogoff and Manuel Savastano, 2003, "Debt Intolerance," Brookings Papers on Economic Activity, No. 1.

Saravia, Diego, 2004, "On the Role and Effects of IMF Seniority," University of Maryland Ph.D. Thesis (www.lib.umd.edu/drum/bitstream/1903/1579/1/umi-umd-1650.pdf).

Uribe, Martin and Vivian Yue, 2006, "Country Spreads and Emerging Countries: Who Drives Whom?," Journal of International Economics, vol. 69, pp. 6-36.

Yue, Vivian, 2005, "Sovereign Default and Debt Renegotiation," University of Pennsylvania mimeo.

Zettelmeyer, Jeromin, 2005, "Implicit Transfers in IMF Lending, 1973-2003," IMF Working Paper 05/8. 
Table 1: Average interest rates

\begin{tabular}{lcccc}
\hline \hline & IMF & \multicolumn{3}{c}{ U.S. government bonds } \\
\cline { 2 - 5 } & Adjusted rate of charge & 2 -yr & 3 -yr & 5 -yr \\
\hline $1986-2008$ & 5.5 & 5.3 & 5.5 & 5.8 \\
$1986-1996$ & 6.8 & 6.6 & 6.8 & 7.1 \\
$1997-2008$ & 4.2 & 4.1 & 4.3 & 4.6 \\
\hline \hline
\end{tabular}

Note: Historical averages for the quarterly IMF adjusted rate of charge, market yield on U.S. Treasury securities at 2-year, 3-year and 5-year constant maturity in percentages. Source: IMF Finance Department and The Federal Reserve Board.

Table 2: Data Moments: Private Sector Creditor Lending

\begin{tabular}{lcccc}
\hline \hline & \multicolumn{4}{c}{ annual } \\
\cline { 2 - 5 } & Period & $\rho(\Delta d / y, y)$ & $\sigma(\Delta d / y)$ & $E[d / y](\%)$ \\
\hline Argentina & $1971-2005$ & 0.32 & 2.87 & 20.63 \\
Brazil & $1971-2005$ & 0.22 & 1.58 & 13.27 \\
Ecuador & $1971-2005$ & 0.33 & 4.26 & 27.63 \\
Indonesia & $1971-2005$ & 0.43 & 2.58 & 9.81 \\
Mexico & $1971-2005$ & 0.25 & 2.67 & 19.17 \\
Peru & $1971-2005$ & 0.14 & 2.78 & 14.36 \\
Philippines & $1971-2005$ & 0.40 & 3.66 & 14.30 \\
Thailand & $1971-2005$ & 0.62 & 10.10 & 10.47 \\
Turkey & $1971-2005$ & 0.62 & 2.94 & 12.35 \\
Mean & & $\mathbf{0 . 3 7}$ & $\mathbf{3 . 7 1}$ & $\mathbf{1 5 . 7 8}$ \\
\hline \hline
\end{tabular}

Note: Correlation of commercial debt flows with real GDP, its standard deviation, and mean stock of commercial debt. Source: Commercial debt data is from World Bank's Global Development Finance Database and it includes bonds, commercial banks, and other debt to private creditors. Real GDP data are GDP volume index from IFS. 
Table 3: Data Moments: IMF Lending

\begin{tabular}{lcccc}
\hline \hline & \multicolumn{4}{c}{ quarterly } \\
\cline { 2 - 5 } & Period & $\rho\left(\Delta d^{*} / y, y\right)$ & $\sigma\left(\Delta d^{*} / y\right)$ & $E\left[d^{*} / y\right](\%)$ \\
\hline Argentina & $1993-2006$ & -0.15 & 1.34 & 4.27 \\
Brazil & $1995-2006$ & -0.24 & 1.65 & 4.49 \\
Ecuador & $1991-2006$ & -0.08 & 0.81 & 3.55 \\
Indonesia & $1997-2006$ & -0.29 & 3.04 & 16.70 \\
Mexico & $1981-2006$ & -0.18 & 0.35 & 1.49 \\
Peru & $1979-2006$ & -0.06 & 0.70 & 7.29 \\
Philippines & $1981-2006$ & -0.14 & 0.87 & 8.61 \\
Thailand & $1993-2006$ & 0.18 & 0.01 & 0.14 \\
Turkey & $1987-2006$ & -0.43 & 2.25 & 9.59 \\
Mean & & $\mathbf{- 0 . 1 5}$ & $\mathbf{1 . 2 2}$ & $\mathbf{6 . 2 4}$ \\
\hline \hline
\end{tabular}

Note: Correlation of IMF debt flows with real GDP, its standard deviation, and mean stock of IMF debt. Source: IFS. IMF debt data is the use of Fund credit: GRA and real GDP data are GDP volume index.

Table 4: Spreads and Use of IMF Credit

\begin{tabular}{lcccc}
\hline \hline & Period & $E\left[s \mid d^{*}>0\right]$ & $E\left[s \mid d^{*}=0\right]$ & $\rho\left(I_{d *>0}, s\right)$ \\
\hline & & & & \\
Argentina & 1994Q1-2006Q4 & $2143(48)$ & $343(4)$ & 0.22 \\
Brazil & 1994Q2-2006Q4 & $826(46)$ & $257(5)$ & 0.47 \\
Ecuador & 1998Q1-2006Q4 & $1280(34)$ & $3544(2)$ & 0.43 \\
Indonesia & 2004Q2-2006Q4 & $275(10)$ & $183(1)$ & N/A \\
Mexico & 1994Q1-2006Q4 & $618(26)$ & $242(26)$ & 0.67 \\
Peru & 1997Q4-2006Q4 & $460(37)$ & N/A (0) & N/A \\
Philippines & 1994Q1-2006Q4 & $405(51)$ & $191(1)$ & N/A \\
Thailand & 1998Q1-2006Q1 & $199(22)$ & $61(11)$ & 0.57 \\
Turkey & 2000Q1-2006Q4 & $516(28)$ & N/A (0) & N/A \\
Mean & & $\mathbf{8 6 0}$ & $\mathbf{3 4 2}$ & $\mathbf{0 . 4 8}$ \\
\hline \hline
\end{tabular}

Note: Mean bond spreads in periods with and without use of IMF credit and the correlation of IMF debt dummy with spreads. Source: Spreads are based on J.P. Morgan's EMBI Global spread data from Bloomberg. 
Table 5: Probability of Use of IMF Credit

\begin{tabular}{lcc}
\hline \hline & $1970-2007$ & $1945-2007$ \\
\hline Argentina & 0.79 & 0.62 \\
Brazil & 0.62 & 0.60 \\
Ecuador & 0.70 & 0.53 \\
Indonesia & 0.60 & 0.54 \\
Mexico & 0.57 & 0.33 \\
Peru & 0.93 & 0.59 \\
Philippines & 0.99 & 0.73 \\
Thailand & 0.57 & 0.74 \\
Turkey & 0.81 & 0.65 \\
Mean & $\mathbf{0 . 7 3}$ & $\mathbf{0 . 4 9}$ \\
Mean w/ 8 other EMEs & $\mathbf{0 . 5 5}$ & $\mathbf{0 . 4 6}$ \\
\hline \hline
\end{tabular}

Note: The additional countries included in the last row are Chile, Colombia, Egypt, India, Korea, Malaysia, Singapore, and Venezuela. Source: IFS.

Table 6: Parameters

\begin{tabular}{lll}
\hline \hline$\sigma$ & 2 & Literature \\
$r$ & $1 \%$ & Literature \\
$\theta$ & $10 \%$ & Literature \\
$\rho$ & 0.91 & Data \\
$\sigma_{z}$ & $1.92 \%$ & Data \\
$\hat{y}$ & 0.93 & To match number of defaults \\
$k$ & 1.42 & To match $E\left[d^{*}\right]$ \\
$\beta^{L}$ & 0.88400 & To match number of defaults \\
$\beta^{H}$ & 0.88415 & To match $\operatorname{Prob}\left(d^{*}>0\right)$ \\
\hline \hline
\end{tabular}


Table 7: Business Cycle Statistics

\begin{tabular}{lcc}
\hline \hline & Data & Model \\
\hline$E[d]^{A}$ & 21.54 & 12.38 \\
$E\left[d^{*}\right]$ & 3.36 & 3.27 \\
\hline$\sigma(y)$ & 4.32 & 4.42 \\
$\sigma(c) / \sigma(y)$ & 1.17 & 1.62 \\
$\sigma(T B / y)$ & 1.44 & 4.49 \\
$\sigma(\Delta d / y)^{A}$ & 2.87 & 2.93 \\
$\sigma\left(\Delta d^{*} / y\right)$ & 1.34 & 2.98 \\
$\sigma(s)^{A}$ & 3.17 & 4.59 \\
\hline$\rho(\Delta d / y, y)^{A}$ & 0.32 & 0.28 \\
$\rho\left(\Delta d^{*} / y, y\right)$ & -0.15 & -0.07 \\
$\rho(s, y)$ & -0.59 & -0.27 \\
$\rho(c, y)$ & 0.98 & 0.87 \\
$\rho(T B / y, y)$ & -0.89 & -0.22 \\
$\rho\left(I_{d^{*}>0}, s\right)$ & 0.22 & 0.25 \\
\hline No. of defaults & 70 & 69.8 \\
$\operatorname{Pr}\left(d^{*}>0\right)$ & 0.62 & 0.65 \\
\hline \hline
\end{tabular}

Note: Series marked with superscript 'A' are annual.

Table 8: IFI Debt During High and Low Spreads

\begin{tabular}{lcc}
\hline \hline & \multicolumn{2}{c}{$E\left[d^{*}\right]$} \\
\cline { 2 - 3 }$s$ & Data & Model \\
\hline$<25$ pct & 1.96 & 2.98 \\
$>75$ pct & 2.05 & 3.04 \\
$D=1$ & 7.97 & 7.52 \\
\hline \hline
\end{tabular}

Table 9: IFI Debt During Booms and Busts

\begin{tabular}{lcc}
\hline \hline & \multicolumn{2}{c}{$E\left[d^{*}\right]$} \\
\cline { 2 - 3 }$y$ & Data & Model \\
\hline$<-\sigma_{y}$ & 8.55 & 5.79 \\
$>+\sigma_{y}$ & 1.53 & 0.83 \\
\hline \hline
\end{tabular}


Table 10: Sensitivity

\begin{tabular}{lccccc}
\hline \hline & & \multicolumn{2}{c}{ Conditionality } & & \\
\cline { 3 - 4 } & Baseline & None & High & $k=1.43$ & $k=1.41$ \\
\hline$E[d]^{A}$ & 12.38 & 12.57 & 12.22 & 12.25 & 12.26 \\
$E\left[d^{*}\right]$ & 3.27 & 3.55 & 2.96 & 2.81 & 3.37 \\
\hline$\sigma(y)$ & 4.42 & 4.43 & 4.45 & 4.41 & 4.47 \\
$\sigma(c) / \sigma(y)$ & 1.62 & 1.62 & 1.60 & 1.63 & 1.64 \\
$\sigma(T B / y)$ & 4.49 & 4.56 & 4.44 & 4.41 & 4.47 \\
$\sigma(\Delta d / y)^{A}$ & 2.93 & 2.99 & 2.90 & 2.95 & 2.99 \\
$\sigma\left(\Delta d^{*} / y\right)$ & 2.98 & 2.81 & 3.11 & 2.69 & 2.92 \\
$\sigma(s)^{A}$ & 4.59 & 4.50 & 4.75 & 4.08 & 4.60 \\
\hline$\rho(\Delta d / y, y)^{A}$ & 0.28 & 0.28 & 0.27 & 0.27 & 0.27 \\
$\rho\left(\Delta d^{*} / y, y\right)$ & -0.07 & -0.04 & -0.05 & -0.06 & -0.06 \\
$\rho(s, y)$ & -0.27 & -0.22 & -0.21 & -0.24 & -0.24 \\
$\rho(c, y)$ & 0.87 & 0.86 & 0.87 & 0.86 & 0.87 \\
$\rho(T B / y, y)$ & -0.22 & -0.21 & -0.20 & -0.22 & -0.20 \\
$\rho\left(I_{d^{*}>0}, s\right)$ & 0.25 & 0.12 & 0.15 & 0.22 & 0.24 \\
\hline No. of defaults & 69.8 & 69.0 & 73.0 & 60.6 & 73.4 \\
$\operatorname{Pr}\left(d^{*}>0\right)$ & 0.65 & 0.90 & 0.58 & 0.53 & 0.68 \\
\hline \hline
\end{tabular}

Figure 1: IMF Interest Rates vs U.S. Government Bond Yields

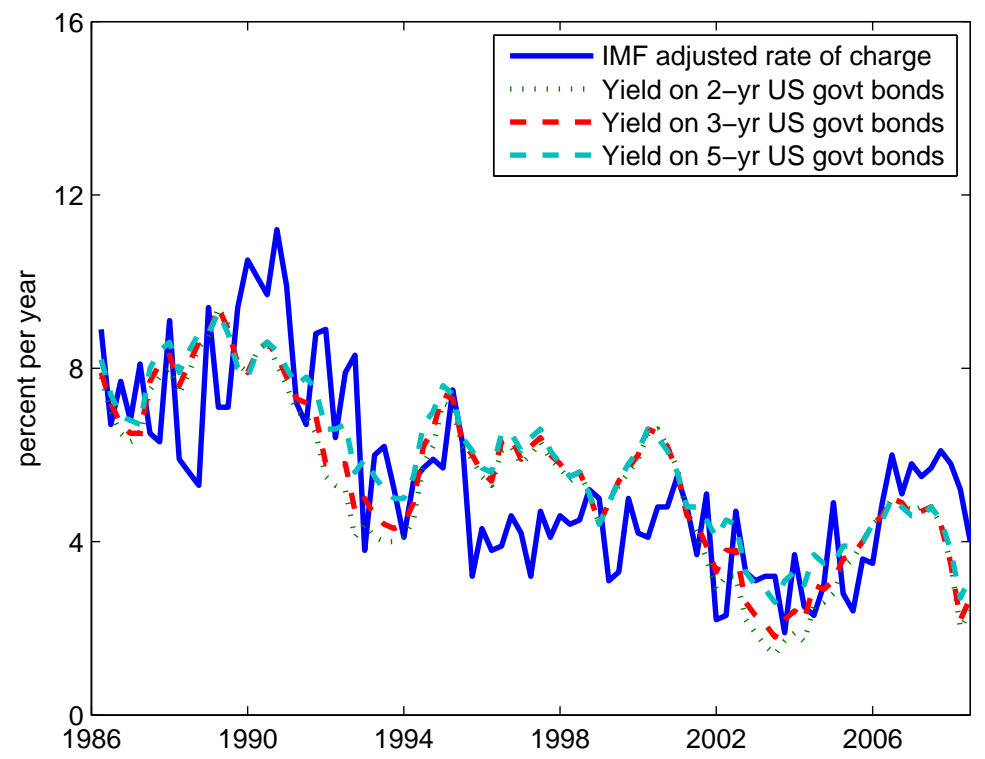


Figure 2: Commercial Debt Price Schedule, $q\left(d^{\prime}, d^{* \prime}, y\right)$

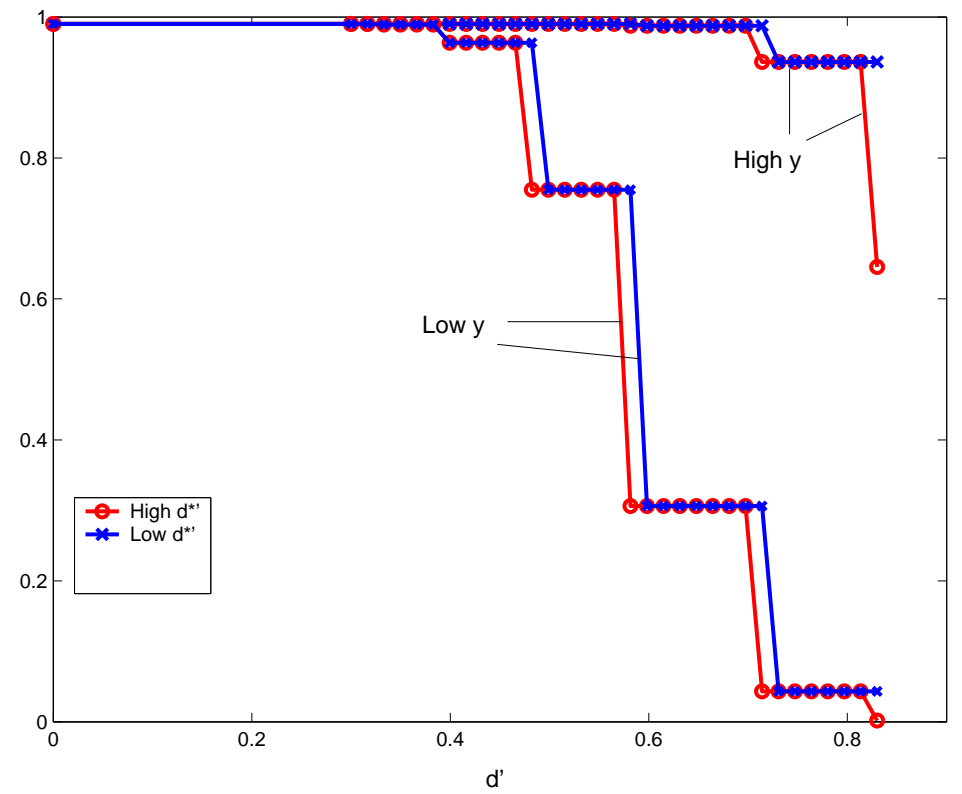

Figure 3: Stationary Bond Distributions for the Simple SOE Model

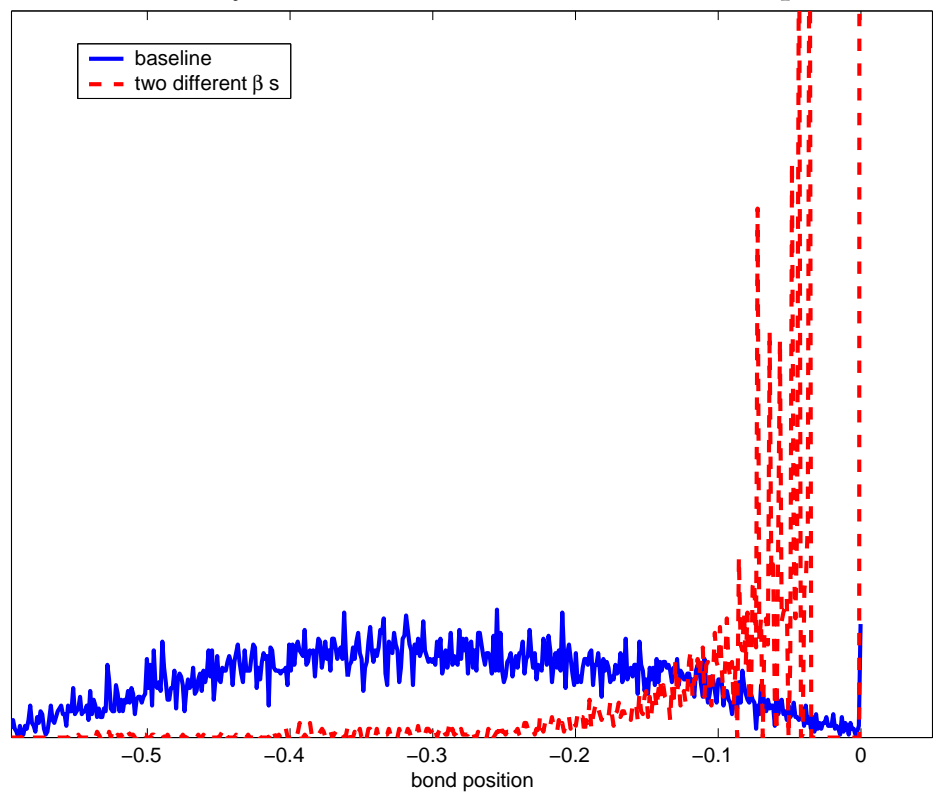

